\title{
PENERAPAN KOMUNIKASI PEMBANGUNAN BERKELANJUTAN DALAM PENGELOLAAN DESA WISATA BERBASIS KEARIFAN LOKAL DI YOGYAKARTA
}

\author{
Pupung Arifin \\ Prodi Ilmu Komunikasi, Universitas Atma Jaya Yogyakarta, Jalan Babarsari No.6, Yogyakarta \\ pupung.arifin@uajy.ac.id \\ Nicolaus Nino Ardhiansyah \\ Prodi Arsitektur, Universitas Atma Jaya Yogyakarta, Jalan Babarsari No.44, Yogyakarta
}

\begin{abstract}
The number of tourist visiting Special Province of Yogyakarta increases in positive trend. Bantul Regency is one of the leading tourism regions in the Province of DIY due to its natural tourism, from beaches to mountain tourism. The focus of the research is on the concept of sustainable development communication because of the issue of collectivity in rural communities that is still thick. This qualitative research uses the method of exploring the meaning of a phenomenon. Researchers found that the main principle in sustainable development is humans. The training and discussion by Pinus Pengger tour operators aims as an ecological option in management. One way is to replace the raw material for photo spots with bamboo. Promotions that rely on social media also continue to be done to reduce the use of plastic and paper as promotional media. The local culture of collectivism and mutual cooperation have long been in the village, becoming one of the pillars of social capital for the success of the principle of sustainable development in the tourist village.
\end{abstract}

Keywords: Tourism, Development Communication, Sustainable, Local Wisdom

\begin{abstract}
Abstrak
Perkembangan jumlah wisatawan ke Daerah Istimewa Yogyakarta (DIY) menunjukkan tren yang positif. Kabupaten Bantul termasuk salah satu daerah unggulan pariwisata di Provinsi DIY karena kelengkapan wisata alamnya, mulai dari pantai hingga wisata pegunungan. Fokus penelitian pada konsep komunikasi pembangunan berkelanjutan karena isu kolektivitas masyarakat rural yang masih kental. Penelitian kualitatif ini menggunakan metode eksplorasi makna dari sebuah fenomena. Peneliti menemukan bahwa prinsip utama dalam pembangunan berkelanjutan adalah manusia. Pelatihan dan diskusi oleh pengelola wisata Pinus Pengger bertujuan sebagai opsi ekologis dalam pengelolaan. Salah satunya adalah dengan mengganti bahan baku spot foto dengan bambu. Promosi yang mengandalkan media sosial juga terus dilakukan untuk mengurangi penggunaan plastik dan kertas sebagai media promosi. Budaya lokal kolektivisme dan gotong royong sudah sudah lama berada di desa tersebut, menjadi salah satu pilar modal sosial untuk suksesnya prinsip pembangunan berkelanjutan di desa wisata.
\end{abstract}

Kata kunci: Pariwisata, Komunikasi Pembangunan, Berkelanjutan, Kearifan Lokal 


\section{PENDAHULUAN}

Pemerintah, Indonesia sudah menetapkan fokus program pembangunan pada lima sektor, yaitu infrastruktur, maritim, energi, pangan dan pariwisata (pikiranrakyat.com, 2017). Dari kelima sektor tersebut, pariwisata dipilih sebagai leading sector pertumbuhan ekonomi Indonesia. Pemerintah menargetkan ada 20 juta kunjungan wisatawan mancanegara pada tahun 2019. Pemilihan sektor pariwisata sebagai ujung tombak karena dianggap mampu menjadi mensinergikan perkembangan setiap sektor dan adanya jaminan pertumbuhan yang positif di ini. Kementerian Perencanaan Pembangunan Nasional/Bappenas juga sudah menetapkan target tersebut dalam publikasinya. Secara rinci dapat dilihat pada tabel berikut ini.

Tabel 1.1. Sasaran Pembangunan Pariwisata $2015-2019$

\section{Sasaran}

1. Kontribusi terhadap PDB Nasional

2. Wisatawan Mancenegara (orang)

3. Wisatawan Nusantara (kunjungan)

4. Devisi (triliun rupiah)

Sumber: (Bappenas, 2014)

Bersadasarkan tabel 1.1. dapat diketahui bahwa adanya lompatan target yang cukup eksoponensial terkait sasaran pembangunan pariwisata pada tahun 2014 dan 2019. Pemerintah menargetkan 8\% PDB nasional pada tahun 2019 dikontribusikan oleh sektor pariwisata. Target tersebut terbilang cukup optimis bila dibandingkan tahun 2014 yang hanya $4,2 \%$ saja. Jumlah masif juga terlihat pada target kunjungan wisatawan mancanegara yang mencapai 20 juta orang. Target ini terbilang cukup optimis juga bila dibandingkan dengan fakta tahun 2014 yang hanya mencapai 9 juta orang wisatawan asing.

Pemerintah Indonesia juga sudah menetapkan 10 Bali baru yang digunakan sebagai motor dalam mencapai target kunjungan tersebut (cnnindonesia.com, 2018). 10 destinasi baru tersebut adalah Danau Toba, Tanjung Kelayang, Tanjung Lesung, Pulau Seribu, Candi Borobudur, Mandalika, Gunung Bromo, Wakatobi, Labuan Bajo, dan Morotai. Selain 10 destinasi wisata unggulan tersebut, Indonesia juga memiliki beberapa wilayah yang secara tradisional sudah menjadi pilihan wisatawan untuk berlibur. Berikut data terkait provinsi tujuan wisata pada tahun 2017.

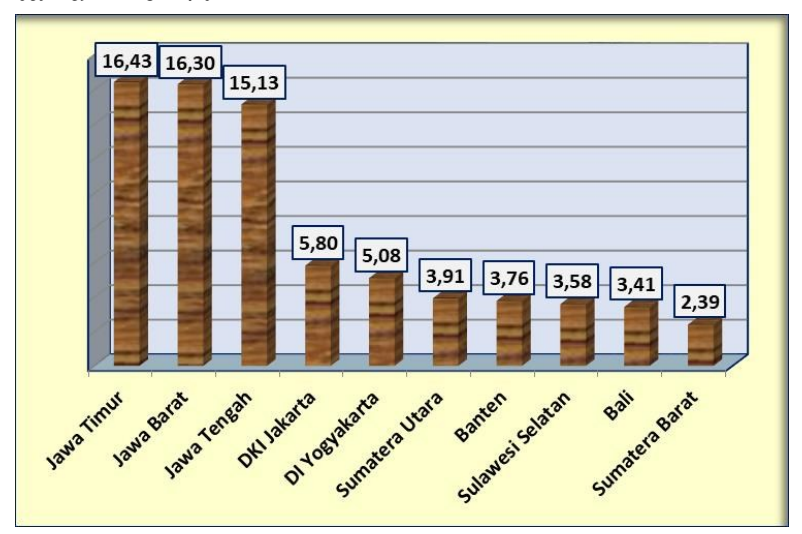

Grafik 1.1. Provinsi Tujuan

Perjalanan Wisatawan Nusantara Sumber: (Barudin, 2017)

Berdasarkan tabel tersebut, Pulau Jawa masih menjadi destinasi favorit wisatawan Nusantara dengan persentase lebih dari $50 \%$ total kunjungan wisatawan domestik nasional. Daerah Istimewa Yogyakarta (DIY) mampu menarik perhatian 5,08 \% turis mancanegara dari total kunjungan di seluruh Indonesia pada tahun 2017. Perkembangan jumlah wisatawan ke Daerah Istimewa Yogyakarta (DIY) menunjukkan tren yang positif. Berdasarkan data dari Badan Pusat Statistik (BPS), jumlah kunjungan wisatawan asing ke Yogyakarta pada tahun 2016 meningkat $41,89 \%$ dan termasuk peningkatan 
tertinggi di Indonesia (Mujib, 2019). Hal ini tidak terlepas dari perpaduan daya tarik potensi alam dan budaya yang dimiliki oleh DI Yogyakarta. Selain obyek wisata yang sudah terkenal seperti Kraton Yogyakarta, Candi Prambanan dan Malioboro, Yogyakarta juga didukung oleh obyek wisata baru seperti Gua Pindul, Pantai Nglambor dan Hutan Pinus Mangunan.

Kabupaten Bantul, sebagai satu dari lima Kabupaten/Kota di Provinsi DIY merupakan salah satu daerah dengan kunjungan wisatawan tertinggi pada tahun 2017. Dinas Pariwisata DIY menyebutkan bahwa pada tahun 2017 terdapat 9 juta wisatawan datang ke Bantul, lalu di peringkat kedua ada Kabupaten Sleman dengan 6,8 juta wisatawan (Dinas Pariwisata DIY, 2019). Kabupaten Bantul masih menjadikan wisata alam untuk menjadi tulang punggung destinasi wisata. Pantai Parangtritis, Pantai Samas, Pantai Pandansimo, Pantai Kuwaru, Goa Cemara, dan Goa Selarong adalah tujuh destinasi dengan kunjungan tertinggi pada tahun 2017 (Badan Pusat Statistik Kabupaten Bantul, 2019).

Kabupaten Bantul memang termasuk salah satu daerah unggulan pariwisata di Provinsi DIY karena kelengkapan wisata alamnya, mulai dari pantai hingga wisata pegunungan. Salah satu spot wisata yang menjadi primadona wisatawan adalah obyek wisata hutan pinus, antara lain: Pinus Pengger, Becici, Dahromo, Pinus Asri, Seribu Batu dan lain-lain. Kawasan hutan pinus di Bantul ini termasuk yang berkembang pesat karena mengalami kenaikan jumlah wisatawan hingga 400\% pada tahun 2017 (Dinas Pariwisata DIY, 2019). Peningkatan tersebut adalah prosentase tertinggi dari seluruh obyek wisata di Kabupaten Bantul.

Salah satu lokasi yang menjadi daya tarik baru di Bantul adalah wisata Pinus
Pengger, Kecamatan Dlingo, Bantul yang resmi dibuka pada bulan April 2016. Daya tarik utama hutan pinus ini adalah spot-spot foto dengan instalasi seni kreasi pengelola dan berlatar belakang pemandangan kota Yogyakarta dari atas. Wisata hutan Pinus Pengger ini dikelola oleh kelompok masyarakat setempat yang bergabung dalam Kelompok Tani Pinus Asri, Blok Terong. Berdasarkan observasi awal peneliti, ditemukan bahwa pengelola menghadapi berbagai kendala, antara lain: belum ada pengelolaan sampah yang terpadu, rendahnya kesadaran customer oriented dari pengelola, tingginya penggunaan plastik, terbatasnya variasi aktivitas wisata, terbatasnya jumlah bahan baku ranting pohon untuk membuat spot foto dan belum adanya zonasi yang jelas dalam penataan kawasan hutan pinus Pengger.

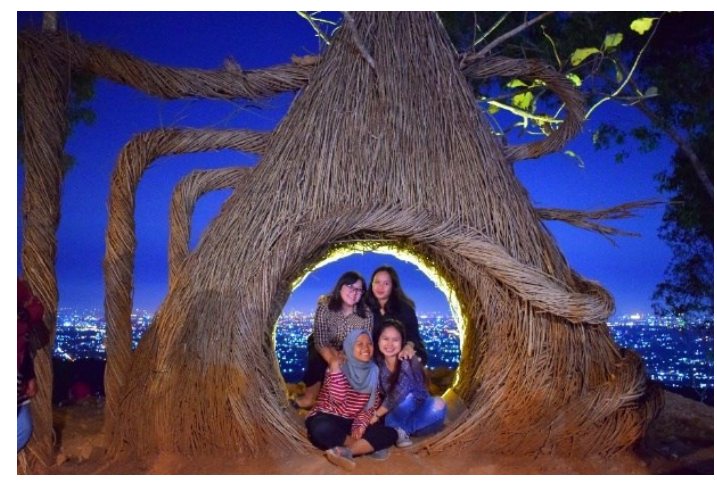

Gambar 1

Spot Foto di Hutan Wisata Pinus Pengger

Sumber: Dokumentasi Peneliti, 2019

Penelitian ini berfokus pada konsep komunikasi pembangunan berkelanjutan karena isu kolektivitas masyarakat rural yang masih kental. Kolektivitas dan gotong royong yang menjadi ciri khas masyarakat desa menjadi tantangan sekaligus peluang dalam pengelolaan konsep pariwisata yang berkelanjutan. Keberhasilan pembangunan berkelanjutan akan ditentukan oleh penerimaan setiap stakeholder atas perubahan yang ditawarkan, dan sejauh mana keterlibatan mereka dalam penentuan 
perubahan yang akan dilakukan. Prinsip komunikasi dalam pembangunan berkelanjutan harus menjamin terjadinya partisipasi dan pemberdayaan komunitas setempat agar budaya lokal tetap dapat terjaga untuk mencapai pariwisata yang ramah lingkungan. Penelitian ini mencoba untuk mengeksplorasi penerapan komunikasi pembangunan berkelanjutan dalam pengelolaan pariwisata oleh masyarakat lokal.

Komunikasi pembangunan yang menjadi dasar banyak proyek di dunia, kerap menggunakan prinsip komunikasi partisipatif dalam pelaksanaannya (Thomas, 2008). Prinsip ini menekankan pada upaya secara sadar untuk melibatkan manusia/komunitas untuk pembangunan mereka sendiri. Model ini telah berhasil dilakukan di banyak negara di dunia. Sayangnya, keberhasilan komunikasi partisipatif ini kemudian mendorong beberapa lembaga non pemerintah (LSM) maupun pemerintah untuk membawa prinsip partisipatif ini lepas dari tujuan utamanya. Partisipatif pada intinya terkait dengan kata kunci akar rumput, berpusat pada komunitas, inklusif, dan adanya perubahan yang lebih baik bagi komunitas tersebut. Masalah utama yang muncul adalah definisi kebutuhan yang cenderung sudah didesain sejak awal oleh LSM maupun pemerintah. Thomas (2008) mengingatkan kembali bahwa dengan terlibatnya Teknologi Informasi (TI) dalam sistem penyampaian, maka isu-isu kontekstual semacam politik, ekonomi, relasi kuasa, dan perubahan sosial kerap dilupakan. Pentingnya aspek komunikasi partisipatif dalam pembangunan ketika secara demokratis anggota komunitas melakukan pendampingan atas perkembangan dari sebuah proses demi kepetingan komunitas mereka sendiri (Gumucio-Dagron, 2008). Prinsip partisipatif inilah yang kemudian juga mendasari pentingnya aspek komunikasi dalam pembangunan berkelanjutan.

Earth Summit di Rio de Janeiro Brasil pada tahun 1992 (Keating, 1992), sudah menegaskan bahwa pembangunan berkelanjutan harus menjamin adanya pertemuan yang setara antara pembangunan dan lingkungan yang dibutuhkan oleh generasi sekarang hingga generasi di masa depan. Dalam perkembangannya, tidak pernah ada pedoman yang tunggal tentang pembangunan berkelanjutan sehingga setiap organisasi memiliki definisinya masing-masing. Pada intinya disepakati bahwa aspek lingkungan hidup dan pembangunan daerah pedesaan/pinggiran. Ada peralihan paradigma bahwa komunitas lokal mulai memiliki tanggung jawab terhadap lingkungan dan sumber daya alam, yang sebelumnya dianggap hanya menjadi tanggung jawab pemerintah (Prasad, 2007).

Sutamihardja (2004) menegaskan beberapa tujuan dari pembangunan berkelanjutan, antara lain:

a. Pemerataan manfaat hasil-hasil pembangunan antar generasi. Perlu ada batas kewajaran dalam pemanfaatan sumberdaya alam berdasarkan daya dukung ekosistem yang replaceable dan mengurangi eksploitasi sumberdaya yang unreplaceable.

b. Safegurading, atau pengamanan terhadap sumber daya alam untuk mencegah ketidakseimbangan ekosistem untuk menjamin tingginya kualitas hidup di masa mendatang.

c. Mempertahankan kesejahteraan rakyat pada masa kini dan masa depan.

d. Mempertahankan kesejahteraan rakyat yang berkelanjutan.

e. Mempertahankan manfaat pembangunan yang dapat dirasakan secara jangka panjang. 
f. Menjaga mutu kualitas kehidupan anggota komunitas antar generasi sesuai dengan habitatnya.

Keterlibatan berbagai stakeholder untuk menjamin terlaksananya komunikasi pembangunan berkelanjutan adalah sebuah keniscayaan. Bagan berikut nampaknya bisa digunakan untuk melihat sinergi tersebut:

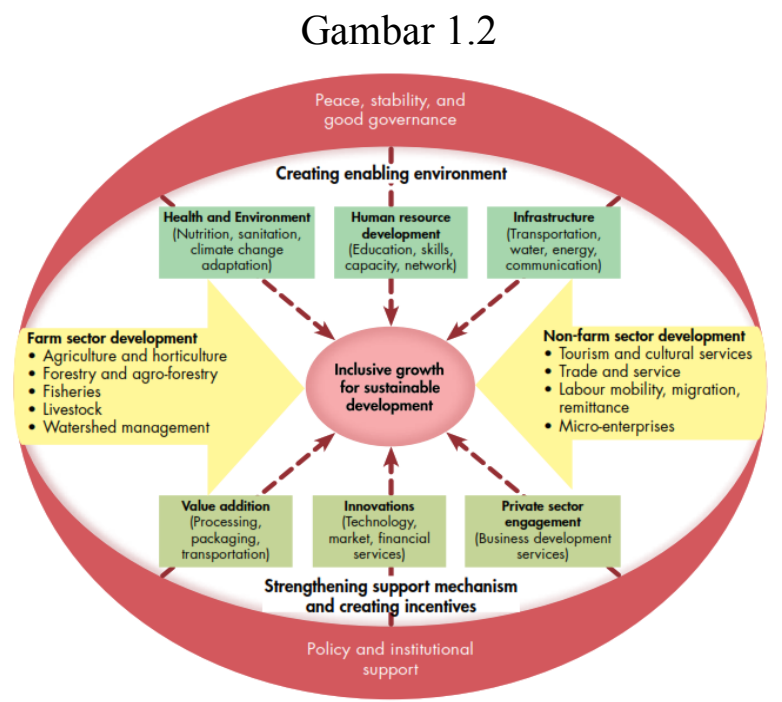

Framework Pembangunan Berkelanjutan

Sumber: Rasul (2015, hlm. 13)

Gambar 1.2 tersebut menunjukkan bahwa kedamaian, stabilitas, tata kelola pemerintahan yang baik, kebijakan dan support institusi menjadi konteks dalam keberhasilan program pembangunan berkelanjutan. Perkembangan pembangunan berkelanjutan memegang prinsip inklusif yang melibatkan keterlibatan berbagai sektor (Rasul, 2015).

Berkaca pada berbagai persoalan dalam pembangunan yang masih bersifat top down, maka komunikasi pembangunan berkelanjutan dapat dipilih sebagai alternatif solusi. Pada skala nasional, komunikasi pembangunan berkelanjutan adaah suatu proses saling mengerti dan memahami antara pemerintah dan warga negaranya menuju suatu masyarakat yang terjamin masa depannya, dimana nilai-nilai dan norma-norma keadilan dijunjung (Cahyandito, 2006). Komunikasi dalam pembangunan berkelanjutan dapat dilihat dari tiga dimensi tujuan, yaitu komunikasi untuk perubahan perilaku, komunikasi untuk perubahan sosial (komunikasi partisipatif), dan komunikasi untuk advokasi (Mefalopulos, 2005).

Secara khusus, komunikasi dalam pembangunan berkelanjutan harus bisa memfasilitasi pemahaman bersama dan saling percaya agar tujuan utama dapat tercapai. Komunikasi pembangunan berkelanjutan tidak bisa menempatkan masyarakat lokal sebagai obyek, namun pelaku utama. Praktek yang banyak terjadi lebih bersifat satu arah dari pemerintah atau organisasi tertentu kepada masyarakat pedesaan (Servaes, 2009). Komunikasi untuk pembangunan berkelanjutan harus bisa lepas dari prinsip "komunikasi" dan "pesan" untuk "membangun sebuah realitas" dan "makna intersubjetivitas". Komunikasi untuk pembangunan berkelanjutan adalah tentang memahami, saling membandingkan, dan saling berbagi realitas oleh bermacam stakeholder, jauh sebelum memikirkan definisi atau konsep pesan yang akan disampaikan (Mefalopulos, 2005). Komunikasi pembangunan tradisional masih mengutamakan prinsip transmisi nilai/pesan, namun komunikasi pembangunan berkelanjutan menegaskan bahwa proses sosial adalah hal pokok dalam membangun tujuan dan rencana pembangunan (Parahita, 2018).

Indonesia masih menghadapi
tantangan dalam mempraktekkan
komunikasi pembangunan berkelanjutan.
Hal ini karena sudah menjadi kebiasaan
bahwa pihak yang lebih berkuasa, akan
memberikan informasi satu arah kepada
obyek komunikannya. Kuasa ini bisa
berupa struktural, usia, pengalaman, kelas

Indonesia masih menghadapi tantangan dalam mempraktekkan komunikasi pembangunan berkelanjutan. Hal ini karena sudah menjadi kebiasaan bahwa pihak yang lebih berkuasa, akan memberikan informasi satu arah kepada obyek komunikannya. Kuasa ini bisa berupa struktural, usia, pengalaman, kelas 
ekonomi, kelas sosial, maupun pendidikan. Hal ini menjadi sesuatu yang wajar karena komunikator tidak mencoba untuk menempatkan komunikan sebagai mitra namun target. Komunikan juga dalam hal ini jarang merasa bahwa mereka bisa terlibat lebih dalam komunikasi pembangunan karena faktor kultrural dan budaya sebagian besar wilayah Indonesia yang cenderung lebih mencoba untuk menjaga harmoni komunitas.

Komunikasi pembangunan berkelanjutan juga perlu menjamin bahwa nilai-nilai lokal menjadi pertimbangan utama dalam proses dinamika pada komunitas lokal. Rakib (2017) menegaskan bahwa pengembangan ekonomi kreatif bagi masyarakat lokal bukan hanya diukur dari unsur ekonomi, namun juga dari aspek budaya. Pengelolaan wisata berkelanjutan di Pinus Pengger mengutamakan spot foto wisatawan yang menggunakan sumbersumber alam, seperti bekas akar/ranting pohon. Pembuatan spot foto ini adalah buah dari hasil kreasi dan kreativitas masyarakat sekitar sebagai pengelola Hutan Wisata Pinus Pengger.

Indentitas kultural atau kearifan lokal ditegaskan oleh Eriksen (1993) merupakan identitas yang dikonstruksikan secara lokal dan komunitas yang menjalankan masih hidup pada tempat tersebut. Perlu juga diperhatikan bahwa budaya dan identitas adalah sebuah proses yang terus bergerak, yang menempatkan setiap individu sebagai partisipan aktif dalam mengkonsumsi informasi (Servaes, 2009). Tantangan yang dihadapi kemudian adalah munculnya upaya untuk mengenalkan kearifan lokal tersebut ke tingkat yang lebih global. Ketika ini dilakukan, maka akan ada penyesuian yang mengakibatkan kearifan lokal tersebut akan berubah demi kebutuhan komunitas global. Produksi sebuah kebudayaan populer dan percampuran kebudayan membuat keunikan budaya asli akan menjadi tidak relevan (Iwabuchi, 2000). Model komunikasi pariwisata yang berbasiskan kearifan lokal pada prakteknya mampu memberikan tawaran kebaruan, sebagai oposisi dari model modern yang berbasiskan perkembangan teknologi informasi dan pengetahuan. Model kearifan lokal ini, akan memberikan pengetahuan yang berharga bagi pengunjung sebagai alternatif pemilihan tujuan wisata (Nugraha, Perbawasari, \& Zubair, 2017).

Liburd \& Edwards (2010) menegaskan bahwa pariwisata di beberapa wilayah hanya menjadi bentuk baru dari adanya dependensi dan akulturasi masyarakat lokal terhadap industri pariwisata. Hal ini kemudian berdampak pada praktek-praktek eksploitasi, ketimpangan relasi dan jurang antara yang kaya dan miskin semakin lebar. Berdasarkan hal ini maka pariwisata berkelanjutan menjadi salah satu pendekatan wajib yang digunakan pengelola untuk mengembangkan Pinus Pengger saat ini dan masa mendatang.

Pariwisata Berkelanjutan menjadi hal penting yang harus diperhatikan di Indonesia karena sektor pariwisata negara ini bergantung pada aspek budaya dan lingkungan sebagai daya tarik. Pariwisata berkelanjutan dapat terwujud apabila komunitas yang tinggal di sekitar obyek wisata mampu memahami pentingnya menjamin keseimbangan lingkungan. Para pelaku wisata di Indonesia harus paham bahwa pertumbuhan pariwisata daya dukung lingkungan untuk saat ini dan di masa depan. Negara wajib menjamin keseimbangan kebahagiaan dalam berwisata. Kebahagiaan ini bukan sematamata milik dari wisatawan, namun juga 
masyarakat setempat yang menjadi ujung tombak terjaganya budaya setempat.

Gambar 1.3

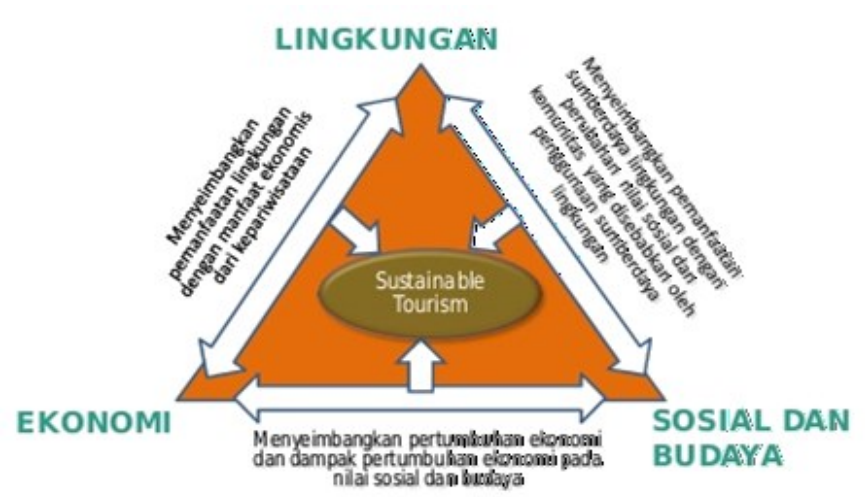

Diagram Konsep Pariwisata Berkelanjutan

Pembangunan berkelanjutan berkaitan erat dengan pertumbuhan ekonomi dan bagaimana mencari jalan untuk memajukan ekonomi dalam jangka panjang dan dapat meningkatkan kesejahteraan generasi sekarang tanpa mengurangi kemampuan alam, masyarakat dan ekonomi untuk menaikan kesejahteraan generasi masa depan. Jadi, jika generasi saat ini bisa maju maka maksud dari diagram konsep pariwisata yang berkelanjutan adalah keberlanjutan ekonomi, lingkungan dan sosial digambarkan sebagai lingkaran yang saling menutupi sebagian dengan keberlanjutan (sustainability) sebagai keadaan di tengahtengahnya. Masyarakat bisa mencapai kesejahteraan, sehingga terdapat alur ekonomi yang berjalan terus menerus, tanpa mengurangi tingkat kesejahteraan dari generasi ke generasi. Pariwisata Hutan Pinus Pengger dalam hal ini telah memberikan dampak ekonomi yang besar bagi warga sekitar, diantaranya pemasukan dari tiket masuk lokasi, spot photo, dan kuliner.

Jadi, jika generasi saat ini bisa maju maka maksud dari diagram konsep pariwisata yang berkelanjutan adalah keberlanjutan ekonomi, lingkungan dan sosial digambarkan sebagai lingkaran yang saling menutupi sebagian dengan keberlanjutan (sustainability) sebagai keadaan di tengah-tengahnya. Masyarakat bisa mencapai kesejahteraan, sehingga terdapat alur ekonomi yang berjalan terus menerus, tanpa mengurangi tingkat kesejahteraan dari generasi ke generasi. Pariwisata Hutan Pinus Pengger dalam hal ini telah memberikan dampak ekonomi yang besar bagi warga sekitar, diantaranya pemasukan dari tiket masuk lokasi, spot photo, dan kuliner.

Aspek sosial dipengaruhi oleh manusia sebagai pendukung komunitas dalam hal interaksi, interrelasi dan interdependesi. Hal-hal yang merupakan perhatian utama dalam aspek sosial adalah stabilitas penduduk, pemenuhan kebutuhan dasar manusia, pertahanan keanekaragaman budaya dan partisipasi masyarakat lokal dalam pengambilan keputusan. Dampak pertumbuhan ekonomi pada nilai social dan budaya masih kurang. Perlu adanya pendekatan budaya pada konsep pengelolaan Pariwisata Hutan Pinus Pengger. Konsep Wana Wisata Budaya Mataram merupakan salah satu pendekatan budaya yang diusulkan.

Aspek ekologi merupakan factor lingkungan yang banyak disorot ketika membahas tentang sustainable design. Hal ini disebabkan karena aspek ini terkait langsung dengan faktor faktor alami yang ada. Sehingga hal-hal yang menunjukkan degradasi lingkungan jelas terlihat dan terasa. Aspek lingkungan mencakup meminimalkan sampah dan kerusakan lingkungan serta meningkatkan tanggung jawab dan kepedulian terhadap sumber daya alam dan lingkungan.

Wisata Hutan Pinus Pengger menggunakan spot foto sebagai daya tarik utama untuk menarik kunjungan wisata ke destinasi tersebut. Spot foto ini pada 
awalnya ada bantuan desain dari pihak lain di luar pengelola, namun saat ini, pengelola sudah mulai melakukan kreasi atas ide dan kreasi sendiri. Kreasi spot foto menjadi sarana interaksi masyarakat setempat sebagai pengelola dengan wisatawan pengunjung. Maka harapannya ada konsep reciprocity yang memiliki pengertian bahwa semua aspek dalam rancangan desain spot foto kan terkait dan dapat diterapkan ke dalam perancangan yang adaptif, harmonis dengan lingkungan, proses berkelanjutan, memiliki kekhasan solusi yang kontekstual dan membangun ruang interaksi (Bislissin \& Rachmawati, 2013)

\section{METODE PENELITIAN}

Penelitian ini berjenis kualitatif yang menekankan pada pengamatan atas fenomena tertentu lalu dilakukan eksplorasi yang mendalam untuk menemukan substansi makna. Kedalaman analisis dipengaruhi oleh ketersediaan data yang dihimpun selama proses lapangan. Independensi peneliti menjadi penting untuk menentukan kecukupan data yang dimiliki. Basri (2014) menegaskan bahwa fokus penelitian kualitatif ada pada proses dan interpretasi atas hasil. Jenis penelitian ini digunakan untuk memahami cara suatu komunitas atau individu dalam menerima sebuah isu tertentu (Mccusker \& Gunaydin, 2014). Penelitian ini menggunakan metode eksploratif yang bertujuan untuk menggali secara luas tentang sebab atau hal-hal yang mempengaruhi terjadinya sesuatu (Arikunto, 2005). Peneliti mencoba untuk menginventarisir berbagai gejaka yang berkaitan dengan praktek kearifan lokal yang dilakukan pengelola Pinus Pengger dalam kesehariannya. Pola interaksi berbagai stakeholder dan saluran komunikasi yang digunakan oleh pengelola dan stakeholder di sekitarnya.

\section{HASIL DAN PEMBAHASAN}

Wisata Alam Pinus Pengger resmi dibuka pada bulan April 2016 dengan total lahan sekitar 5 hektar dan yang dimanfaatkan untuk wisata sekitar 2,5 hektar atau setengahnya. Hutan yang berada di pinggir jalan antara Jalan Patuk Dlingo ini di bawah kepengurusan Kesatuan Pengelolaan Hutan (KPH) Daerah Istimewa Yogyakarta. Hutan Pinus Pengger yang masih masuk dalam kawasan Resort Pengelolaan Hutan (RPH) Mangunan ini terletak di Dusun Sendangsari, Desa Terong, Kecamatan Dlingo, Kabupaten Bantul. Pinus Pengger berjarak kurang lebih $18 \mathrm{~km}$ dari pusat kota Yogyakarta.

Wisata alam Pinus Pengger memiliki kepengurusan yang disebut Kelompok Tani "Pinus Asri" Blok Terong yang diresmikan tanggal 25 Januari 2016 yang sebagian besar anggotanya (kurang lebih 50 orang) adalah masyarakat Dusun Sendangsari, Terong, Dlingo, Bantul. Pengunjung yang datang ke wisata alam Pinus Pengger ini tidak hanya disuguhkan pemandangan dan suasana hutan pinus saja tetapi juga dimanjakan dengan pemandangan kota Yogyakarta dan Pantai Parangtritis yang dapat dinikmati dari atas bukit Pinus Pengger. Pengunjung selanjutnya juga dapat menikmati matahari terbenam (sunset) atau Gunung Merapi yang juga terlihat jelas dan indah di lokasi tersebut.

Berdasarkan wawancara yang dilakukan pada pra penelitian, diperoleh informasi awal bahwa sebagian besar kegiatan yang dilakukan pengelola hutan wisata Pinus Pengger atas dasar otodidak. Pengelola tidak atau belum pernah mendapatkan pendampingan secara khusus dalam manajemen pengelolaan wisata. Secara lebih lanjut, tantangan yang dihadapi pengelola antara lain: 
1. Kurangnya promosi. Sebagai wisata yang baru Pinus Pengger kurang mempromosikan wisata mulai dari media cetak internet atau elektronik sehingga masih belum terlalu diketahui wisatawan. Promosi selama ini hanya dilakukan dengan metode word of mouth (WoM). Promosi belum dilakukan secara menyeluruh dan terpadu memanfaatkan teknologi seperti video dan fotografi. Pengelola terdiri dari anak muda yang berpotensi besar untuk membuat brosur atau video promosi. Popularitas Pinus Pengger masih kalah dengan Puncak Becici dan Pinus Mangunan yang sudah lebih dahulu ada.

2. Aktivitas wisata yang dilakukan pengunjung masih berpusat pada spot foto saja, belum banyak aktivitas wisata lain yang ditawarkan oleh pengelola sebagai variasi. Padahal daerah sekitar dan warga memiliki beberapa potensi antara lain: seni alam, gambar, lukisan, pentas budaya dan lain-lain. Belum ada acara tahunan yang menjadi ciri khas Pinus Pengger yang menjadi agenda rutin pengelola untuk merebut perhatian umum dan media massa.

3. Sampah yang dihasilkan selama ini hanya menumpuk di tempat terbuka, dan terkadang tidak secara rutin diambil/dibersihkan. Hal ini cukup mengganggu keindahan dan sanitasi lokasi wisata.

4. Limbah yang dihasilkan dari toilet dan warung makan belum dikelola dengan baik sehingga berpotensi menggangu sanitasi, kualitas tanah hutan pinus dan berpotensi mencemari sumber air terdekat.

5. Pengelola kesulitan menyediakan bahan baku instalasi spot foto karena sebagian besar ranting pohon yang digunakan masih berasal dari luar wilayah Dlingo. Hal ini karena untuk perawatan spot foto, harus menggunakan ranting dari pohon khusus yang sifatnya lentur sehingga mudah untuk dibentuk. Ranting yang selama ini digunakan cepat rusak oleh cuaca sehingga harus rutin diganti dan diperbaiki.

6. Belum adanya kesadaran pengelola tentang kualitas pelayanan kepada pengujung. Sehingga tidak ada kesamaan standar pelayanan konsumen antar anggota pengelola. Kualitas pelayanan ini terkait dengan etika berpakaian, etika dalam berkomunikasi dengan tamu, etika bersikap dan berperilaku di area sekitar hutan pinus dan rendahnya kemampuan berbahasa Inggris pengelola.

7. Tidak ada pengaturan zonasi wilayah sehingga berdampak pada ketidakjelasan konsep pengembangan wisata hutan Pinus Pengger yang ramah lingkungan.

Pengelola hutan Pinus Pengger yang berjumlah sebanyak sekitar 50 orang merupakan pengurus inti dan anggota. Pengelola ini kemudian memiliki wewenang untuk mengatur dan mengkoordinasikan berbagai kelompok yang bekerja di lokasi tersebut, mulai dari petugas fotografer di spot foto, pemilik warung, petugas parkir, kebersihan, perawatan, penjaga loket dan lain sebagainya. Pengelola memiliki agenda pertemuan rutin setiap bulan yang menjadi forum bertemunya pengelola inti dengan warga lainnya yang bekerja di Pinus Pengger ini.

Secara sekilas, partisipasi masyarakat dalam menjalankan unsur bisnis di hutan wisata ini cukup baik karena tidak ada intervensi pihak luar yang mengatur pola manajemen di kelompok ini. Partisipasi bottom-up selalu digunakan sebagai prinsip utama dalam setiap alih diskusi dan penentuan keputusan diantara para anggota pengelola. Permasalahan terkait pengelolaan Pinus Pengger tidak hanya dibahas pada satu forum saja, namun juga dalam berbagai forum formal lain pada komunitas masyarakat setempat. 
Forum komunikasi tersebut antara lain pertemuan dusun, pertemuan RT, dasawisma, kelompok tani, dan karang taruna. Selain pertemuan formal, saluran komunikasi lainnya yang rutin digunakan adalah getok tular (words of mouth) dan aplikasi ponsel seperti whatsapp dan sms.

Secara lebih lanjut, komunitas ini masih terkesan memiliki kekurangterbukaan pada partisipasi. Beberapa anggota kelompok yang dianggap lebih senior atau lebih pintar belum menemukan cara agar anggota lainnya yang merasa inferior dapat memiliki ruang dialog yang egaliter tanpa sungkan atau ragu untuk mengungkapkan pendapat. Selain itu, keterlibatan perempuan dalam pengelolaan wisata Pinus Pengger masih cukup minim dan terbatas. Jumlah perempuan yang tidak banyak tersebut lebih mendapatkan peran untuk berjualan makanan dan menjaga warung di dalam maupun di sekitar kawasan wisata.

Partisipasi komunitas dalam pengelolaan sebenarnya memiliki modal yang kuat karena kuatnya prinsip kolektivisme diantara mereka. Mereka memiliki rasa memiliki yang tinggi ankan kelompok tersebut. Mereka berpegang pada prinsip untuk menjaga kesatuan dan harmoni diantara mereka. Pada diskusidiskusi yang dilakukan, jarang ditemui adanya penolakan atau sanggahan atas ideide yang disampaikan oleh pengurus inti. Anggota komunitas menganggap pengurus inti pengelola Pinus Pengger adalah pihak yang paling mampu. Relasi kuasa yang nampak dalam hal ini adalah Kepala Resort Pengelolaan Hutan (RPH) Mangunan, Lurah Desa Terong, Kepala Dusun Sedangsari, tokoh masyarakat setempat, dan pengurus inti kelompok Pinus Asri memiliki posisi sosial dan komunikasi yang lebih tinggi. Prinsip patriarki yang menjadi karakter masyarakat Jawa juga nampak. Maka laki-laki memiliki kekuasaan yang lebih tinggi di dalam perannya sebagai pemimpin.

Terkait hal tersebut, secara lebih lanjut dapat dilihat bahwa masih ada gap komunikasi dan cara pandang dari pengelola dengan pekerja lain yang mensupport jalannya wisata. Pengelola beranggapan bahwa masih ada sebagian besar anggota yang tidak mau mengikuti berbagai peraturan dan kesepakatan. Contohnya terkait dengan penggunaan seragam yang tidak dilakukan oleh seluruh anggota. Hal lain ialah penilaian pengurus kepada beberapa anggota yang tidak menggunakan prinsip pelayanan prima kepada seluruh pengunjung wisata.

Beberapa gejala tersebut dapat diurai apabila pengelola mulai mencoba prinsip komunikasi pembangunan berkelanjutan. Prinsip dasar yang harus digunakan sebagai latar belakang adalah adanya suatu proses saling mengerti dan memahami antar para pihak yang berkepentingan yang tetap menjunjung tinggi nilai-nilai dan normanorma keadilan (Cahyandito, 2006).

Komunikasi dalam pembangunan berkelanjutan harus bisa memfasilitasi pemahaman bersama dan saling percaya agar tujuan utama dapat tercapai. Komunikasi untuk pembangunan berkelanjutan harus bisa lepas dari kotak definisi tradisional "komunikasi" dan "pesan". Prinsip komunikasi tradisional ini yang secara jelas masih nampak terjadi diantara para pengelola Pinus Pengger karena proses sosial adalah hal pokok dalam membangun tujuan dan rencana pembangunan (Parahita, 2018). Prinsip berkelanjutan dapat dikatakan berhasil apabila seluruh elemen yang berkepentingan memiliki posisi yang setara dan adil dalam proses pembangunan. 
Relasi kuasa yang masih nampak dalam komunikasi diantara pengelola masih menjadi salah satu hambatan terwujudnya komunikasi pembangunan berkelanjutan.

Diskusi komunitas yang diamati dalam penelitian ini masih mengarah pada tujuan pembangunan proses sosial. Pariwisata berkelanjutan sendiri dapat terwujud apabila komunitas yang tinggal di sekitar obyek wisata mampu memahami pentingnya menjamin keseimbangan lingkungan. Berdasarkan diskusi, pengelola dan anggota mulai menyadari bahwa bahan baku ranting yang digunakan sudah mulai susah ditemukan dan periode waktu penggantian cukup dekat. Sebagai alternatif, bahan baku bambu tersedia cukup banyak di sekitar hutan pinus tersebut, maka saat ini menjadi alternatif pilihan baru yang kemudian dieksekusi untuk membangun satu spot foto baru dengan bahan baku bambu. Berikut beberapa dokumentasi pembuatan spot foto baru dengan bahan baku bambu.

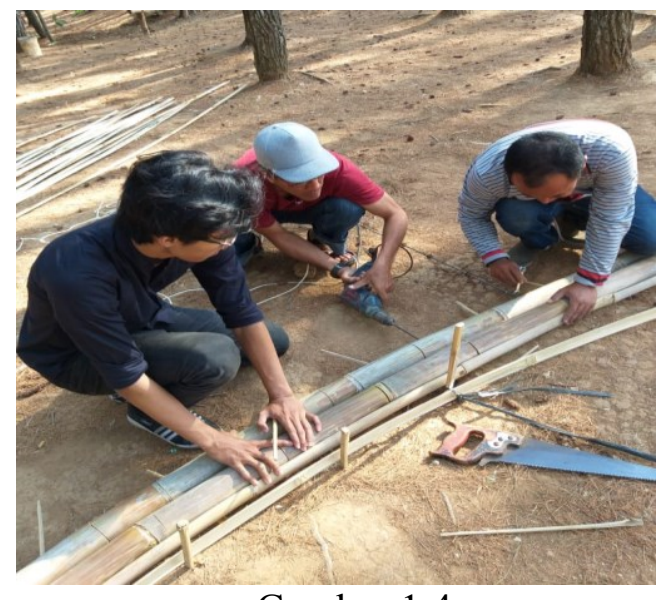

Gambar 1.4

Pembuatan Spot Foto Berbahan Dasar Bambu di Pinus Pengger

Sumber: dokumentasi peneliti, 2019

Peningkatan kapasitas anggota komunitas terkait pelayanan pelanggan dan tawaran aktivitas wisata lain selain spot foto dapat menjadi peluang sekaligus tantangan dalam komunikasi pembangunan (yang dalam hal ini pariwisata) berkelanjutan. Misalnya pelatihan customer relation, fotografi, pemanfaatan limbah/sampah plastik harus dilaksanakan dalam kerangka untuk mengangkat potensi lokal dengan dialog yang berkeadilan, dan bukan semata untuk mengejar aspek ekonomi semata.

\section{PENUTUP}

\section{Simpulan dan Saran}

Pariwisata yang dikembangkan dengan prinsip komunikasi pembangunan berkelanjutan memiliki peluang besar untuk diterapkan di Indonesia khususnya Yogyakarta. Ciri khas pariwisata budaya dan alam di Yogyakarta, yang salah satunya adalah Pinus Pengger, lebih banyak dikelola oleh kelompok masyarakat setempat. Keterbukaan diskusi diantara para pihak memiliki kendaraan budaya yang kaya karena tingginya kolektivitas di masyarakat Jawa. Tantangan juga nampak karena budaya patriaki dan relasi kuasa yang cukup kental bagi pimpinan pemerintahan, tokoh masyarakat dan warga senior.

Peluang diangkatnya kearifan lokal oleh pengelola Pinus Pengger sudah mulai dilakukan ketika membuat spot foto baru dengan bahan dasar bambu. Tentu ada peluang lain yang berupa budaya lokal seperti kebiasaan, ritual, kuliner dan karakter khas masyarakat setempat sebagai salah satu nilai lebih di wisata Pinus Pengger.

\section{DAFTAR PUSTAKA}

Badan Pusat Statistik Kabupaten Bantul. (2019). Kabupaten Bantul dalam Angka. Bantul: BPS Bantul.

Bappenas, D. B. (2014). Pembangunan Pariwisata 2015 - 2019. Jakarta: Bappenas. 
Barudin, I. A. (2017). Kajian Data Pasar Wisatawan Nusantara 2017. Jakarta: Kementerian Pariwisata.

Basri, H. (2014). Using Qualitative Research in Accounting and Management Studies: Not a New Agenda. Journal of US-China Public Administration, 11(10), 831-838. doi:10.17265/1548$6591 / 2014.10 .003$

Bislissin, N., \& Rachmawati, M. (2013). Trilogi Simbiosis: Seni Rupa, Arsitektur dan Ruang Publik. Jurnal Sains dan Seni POMITS, 2(2), 82-86.

Cahyandito, M. F. (2006). Pembangunan Berkelanjutan, Ekonomi dan Ekologi, Sustainability Communication dan Sutainability Reporting.

cnnindonesia.com. (2018, Oktober 14). Indonesia Pamer '10 Bali Baru' di Pertemuan IMF-Bank Dunia. Diambil kembali dari CNN Indonesia:

https://www.cnnindonesia.com/ga ya-hidup/20181014151703-269338377/indonesia-pamer-10-balibaru-di-pertemuan-imf-bank-dunia

Dinas Pariwisata DIY. (2019). Statistik Kepariwisataan 2018. Yogyakarta: Dinas Pariwisata DIY.

Eriksen, T. (1993). Ethnicity and Nationalism, Antropological Perspectives. London: Pluto Pers.

Gumucio-Dagron, A. (2008). Vertical Minds versus Horizontal Cultures: An Overview of Participatory
Process and Experiences. Dalam J. Servaes, Communication for Development and Social Change (hal. 68 - 81). New Delhi: Sage.

Iwabuchi, K. (2000). To Globalise, Regionalise or Localise Us, That is the Question: Japan's Response to Media Globalization. Dalam J. S. G. Wang, The New Communications Landscape Demystifying Media Globalization. London and New York: Routledge.

Keating, M. (1992). The Earth's Summit Agenda for Change. Geneva: Centre for Our Common Future.

Liburd, J., \& Edwards, D. (2010). Understanding the Sustainable Development of Tourism. Oxford: Goodfellow.

Mccusker, K., \& Gunaydin, S. (2014). Research using qualitative, quantitative or mixed methods and choice based on the research. Perfusion, 30(7).

Mefalopulos, P. (2005). Communication for sustainable development: applications and challenges. Dalam Media and Glocal Change: Rethinking Communication for Development (hal. 247 - 259). Buenos Aires: CLASCO.

Mujib, N. (2019). Tingkat Penghunian Kamar Hotel DIY 2018. Yogyakarta: Badan Pusat Statistik DIY.

Nugraha, A., Perbawasari, S., \& Zubair, F. (2017). Model Komunikasi Pariwisata yang Berbasis Kearifan 
Lokal. Jurnal The Messanger, 9(2), $231-240$.

Parahita, G. D. (2018). Shifts and Challenges of Communication for Sustainable Development in Indonesia. Dalam K. Prasad, Communication, Culture and Ecology: Rethinking Sustainable Development in Asia (hal. 155 171). Singapore: Springer.

pikiranrakyat.com. (2017, Desember 13). Optimis Jadikan Pariwisata sebagai Leading Sector Pertumbuhan Ekonomi. Diambil kembali dari https://www.pikiranrakyat.com/advertorial/pr01290726/optimis-jadikanpariwisata-sebagai-leading-sectorpertumbuhan-ekonomi-415783

Prasad, K. (2007). From Eco-religion to Political Ecology in India: Feminist Interventions in Development. Women in Action Vol 2, hal. 32 - 43.

Rakib, M. (2017). Strategi Pengembangan Ekonomi Kreatif Berbasis Kearifan Lokal sebagai Penunjang Daya
Tarik Wisata. Jurnal Kepariwisataan Vol 1 No.2, 54 - 69.

Rasul, G. (2015). A Strategic Framework for Sustainable Development in the Chittagong Hill Tracts of Bangladesh. Kathmandu: International Centre for Integrated Mountain Development.

Servaes, J. (2009). Communication policies, good governance and development journalism. Communicatio Vol 35, 50 - 80.

Sutamihardja. (2004). Perubahan Lingkungan Global. Bogor: Program Studi Pengelolaan Sumber Daya Alam dan Lingkungan Sekolah Pascasarjana IPB.

Thomas, P. (2008). Communication and the Persistence of Poverty: The Need for Return to Basics. Dalam J. Servaes, Communication for Development and Social Change (hal. 31 - 44). New Delhi: Sage. 